\title{
Conservation of the coniferous forests of Lebanon: past, present and future prospects
}

\author{
S. N. Talhouk, R. Zurayk and S. Khuri
}

\begin{abstract}
Coniferous forests are an important component of the Lebanese landscape. Ten species of conifers in five genera are found as wild populations in Lebanon: Cilician fir Abies cilicica, cedar of Lebanon Cedrus libani, Mediterranean cyprus Cupressus sempervirens, Syrian juniper Juniperus drupacea, Grecian juniper $J$. excelsa, willdenow $J$. foetidissima, prickly juniper J. oxycedrus, Calabrian pine Pinus brutia, Aleppo pine $P$. halepensis and stone pine $P$. pinea. Although none of these species are seriously threatened in a global context, they exist in Lebanon mostly as fragmented and degraded populations, and their habitats are under
\end{abstract}

great pressure from urbanization and associated development. Conservation efforts in Lebanon have concentrated mainly on the cedar of Lebanon, with two cedar of Lebanon forests protected as Nature Reserves. Large areas of forest, coniferous and otherwise, remain unprotected. In this review, the need for an integrated approach to conservation of the coniferous landscape of Lebanon and the importance of the participation of local communities in this process are emphasized.

Keywords conifers, conservation, forest, Lebanon, Mediterranean.

\section{Introduction}

The Mediterranean Basin is a recognized region of botanical importance, with a number of areas rich in endemic species (Davis et al., 1994; Myers et al., 2000), including the Levant (Medail \& Quézel, 1997). This area, the western fringe of the Fertile Crescent, has been subject to human influence for thousands of years. The coniferous trees of this region are an important source of timber and food, and have consequently been subject to massive levels of degradation over centuries, resulting in the present threats to their existence (Farjon et al., 1993; Farjon \& Page, 1999). The conservation of this ancient resource needs to take into account changes in the use and perception of the traditional agricultural Mediterranean landscape. In this review, we outline the history and ecology of Lebanese conifers, give a brief account of the species and their habitats, and outline the requirements of a conservation strategy for these conifers and their habitats.

S. N. Talhouk (corresponding author) and R. Zurayk Faculty of Agricultural and Food Sciences, The American University of Beirut, PO Box 11-0236, Riad EI Solh 1107-2020, Beirut, Lebanon. E-mail: ntsalma@aub.edu.lb

S. Khuri School of Plant Sciences, The University of Reading, Whiteknights, PO Box 221, Reading, RG6 6AS, UK. Present address: National Tropical Botanical Garden, 3530 Papalina Road, Kalaheo, Kauai, HI 96741, USA.

Revised manuscript accepted for publication 23 February 2001

\section{Historical context and the need for conservation}

The Lebanese Mountains have supplied the Levant with timber since Phoenician times, and the Ancient Egyptians made regular expeditions to Lebanon to obtain lumber for shipbuilding and temple construction, and cedar of Lebanon Cedrus libani oil for mummification (Wilson, 1955). Because of the exceptional size of the Lebanese conifers there were regular logging expeditions even from Mesopotamia (Speiser, 1955). The cedars of Lebanon were well known to ancient Palestine, and the wood was highly prized not only as a building material but also for its beauty, fragrance and durability. The Romans also used the Levantine conifers as a source of construction and shipbuilding materials (Meiggs, 1982).

There is evidence that systematic woodcutting by classical civilizations over several millennia BC did not extend above an altitude of $1000 \mathrm{~m}$ (Bowton, 1965). It was not until the 7 th century AD that persecuted religious minority groups sought refuge in remote areas on the western mountains, establishing villages at elevations of 1000-1500 m and developing an agropastoral economy. These communities expanded and built an elaborate system of agricultural terraces, although their pastoral activities extended further up into forests of cedars of Lebanon, Cilician fir Abies cilicica and Grecian juniper Juniperus excelsa (Mikesell, 1969).

Under Ottoman rule (from the 16th century until after World War I), logging in Lebanon became an alternative form of tax payments, and as a result increased uncontrollably. Further felling occurred during World 
War I for fuel for the railway connecting Damascus with Aleppo and Beirut. During World War II, Cilician fir and oak (Quercus spp.) in the north-western part of Lebanon, especially in the Qammoua region, were cut by the British forces for the construction of the railway connecting Tripoli and Haifa (Mikesell, 1969).

Outside urban areas, destruction of conifers was mainly due to the expansion of agricultural lands, the use of wood for fuel, and overgrazing (Sanlaville, 1977). Forests were cleared, terraced and cultivated. The terrace walls were carefully maintained, and soil conservation measures were implemented on all lands. However, these terraces were abandoned earlier this century, and have degraded and become covered by a thorny garrigue. Additional deforestation was caused by systematic woodcutting for the lime furnaces that were common up until World War I (Zurayk \& El Moubayid, 1994). Despite the disappearance of these furnaces, charcoal continues to be produced locally, leading to further deforestation.

The impact of this continuous and systematic extraction of Lebanese timber resources has transformed the original extensive forests to relictual patches and scrub vegetation. Although the conifer species in Lebanon are also found, in varying densities and states of degradation, in neighbouring countries in the Mediterranean region and Middle East (Table 1), in the case of the Lebanese conifers it is the whole ecosystem in which they grow that is under threat. The Convention of Biological Diversity, of which Lebanon is a signatory, places a legal and biological responsibility on countries to formulate conservation strategies and to "promote the protection of ecosystems, natural habitats and the maintenance of viable populations of species in natural surroundings' (Glowka et al., 1994). The significance of the Lebanese conifer populations as a genetic resource, and their economic importance for amenity, timber, food and essential oils, is substantial. Conifers also play a vital role in Lebanese culture and traditions, with the cedar of Lebanon being the Lebanese national symbol and the stone pine Pinus pinea being particularly important for food, fuel and furniture.

\section{Distribution and status}

Despite major pressures on the landscape of Lebanon (outlined below), there has been no comprehensive study of the status of Lebanese forests in recent years. The total forested area of Lebanon has been estimated at 70000 ha, including highly degraded stands (FAO, 1993); conifers in both pure and mixed stands constitute almost half the total forested area. Forest cover in Lebanon decreased by 12.5 per cent between 1968 and 1989 (Darwich et al., 1996). There is little up-to-date information on forest cover with respect to individual conifer species (FAO, 2000), and the reports available are either ambivalent, or refer to earlier work reported by Baltaxe (1965). Due to this lack of recent information, some of the data quoted for area covered by forest may be outdated. We have supplemented these data with our own observations and assessments based on fieldwork and surveys conducted during 1997-1999.

\section{Geographical context}

Lebanon covers an area of $10450 \mathrm{sq} \mathrm{km}$, with two parallel mountain ranges extending throughout the length of the country, the Lebanon and Anti-Lebanon, separated by the Beqaa plain. Ten bioclimatic regimes and 22 vegetation associations have been identified (Chouchani, 1972), falling within two major climate zones, the Mediterranean and the pre-steppe areas. The Mediterranean zone includes the narrow coastal strip, the western slopes of the Lebanon mountain chain
Table 1 Conifer species occurring in Lebanon, with their global distribution (Farion, 1998) and 2000 IUCN Red List status (Hilton-Taylor, 2000). Species names follow Post \& Dinsmore (1933) and Mouterde (1966).

\begin{tabular}{lll}
\hline & & Global Red \\
Species name & Global distribution & List status \\
\hline $\begin{array}{l}\text { Abies cilicica (Ant. \& Ky.) } \\
\text { Carr. }\end{array}$ & Lebanon, Syria, Turkey & LR/nt \\
$\begin{array}{ll}\text { Cedrus libani A. Rich. } \\
\text { Cupressus sempervirens L. }\end{array}$ & Lebanon, Syria, Turkey & Eastern Mediterranean, North Africa, NW Iran \\
Juniperus drupacea Labill. & Greece, S Turkey, Syria, Lebanon & LR/nt \\
J. excelsa M.-Bieb. & SE Europe, Crimea, Caucasus, W Asia & - \\
J. foetidissima Willd. & SE Europe, Crimea, Caucasus, W Asia & - \\
J. oxycedrus L. & Mediterranean, Black Sea & - \\
Pinus brutia Ten. & E Mediterranean, Black Sea, Caucasus & - \\
P. halepensis Mill. & From Spain through North Africa to the & - \\
P. pinea L. & E Mediterranean and Syria & - \\
\hline
\end{tabular}

LR/nt: Lower risk/near threatened. 
(up to $2000 \mathrm{~m}$ ) and the eastern side of the mountains of Barouk and Niha. The northern area, extending from the northern border with Syria to Beirut, is the wettest and the southern coastal area extending from the south of Saida to the southern border is the driest. The western slope of the Lebanon mountain chain is the most ecologically diverse area in Lebanon, from the lowest altitudinal zone, which consists of both evergreen and deciduous vegetation, to the subalpine zone, which consists mainly of degraded juniper forests (Zohary, 1973). The pre-steppe areas include the eastern side of the Lebanon mountains, the Anti-Lebanon, and the arid and semiarid Beqaa. The tree species in this area are Grecian juniper at higher altitudes, and species of oak (Quercus infectoria and Q. calliprinos) as mixed stands at lower altitudes (Chouchani, 1972). A 50-km transect from the coast inland can include both Mediterranean areas with nearly $1000 \mathrm{~mm}$ of annual rainfall and presteppe areas with $<250 \mathrm{~mm}$ of rainfall (METAP, 1995). The distribution of conifers in Lebanon is influenced by both the altitudinal and edaphic features of this diverse landscape.

\section{Distribution of the species}

The Lebanese conifer forests are highly fragmented, with only 10 per cent of forest patches occupying areas of more than 200 ha (Baltaxe, 1965), and the relatively few extensive areas of remaining forest are largely open and degraded. The majority of natural forest associations in Lebanon occur over 1200-2000 m, and consist mainly of pure and mixed forest of cedars of Lebanon, Cilician fir and junipers. The distribution range of the former two species extends from Turkey to Lebanon, where they both reach their lower latitudinal limits (Mouterde, 1966; Chouchani, 1972; Farjon, 1998). The species are listed below in altitudinal order, from those characteristic of lower zones to those that occur above $2000 \mathrm{~m}$.

\section{Calabrian pine (P. brutia)}

There are 94 pure stands of Calabrian pine recorded, most of which are degraded and $<100$ ha in area (Baltaxe, 1965). Northern stands are relatively older and denser than those in central areas. The composition of mixed stands in which Calabrian pine is the dominant species varies with altitude: it is usually found associated with oak $Q$. calliprinos at lower altitudes, and Q. infectoria and Q. cerris at higher altitudes. In the 1960s, these mixed stands covered an estimated 867 ha, with an additional 3490 ha of highly degraded forests (Baltaxe, 1965), and they have since declined further (S.N. Talhouk et al., pers. obs.). At its upper altitudinal limit, Calabrian pine is often found in cedar of Lebanon and Cilician fir forests (E. Sattout, pers. comm.). Cala- brian pine is a good coloniser of hillside clearings (Chouchani, 1972), and although it is found mostly at lower altitudes has penetrated the higher mountainous zone into deciduous forests that have been severely damaged and have not had the opportunity to regenerate (Zohary, 1973). For example, Calabrian pine is found above $1200 \mathrm{~m}$ altitude in one region of a mixed forest at Ehden (Sattout, 1998). The long-term ecological implications of these changes in species distribution are as yet unknown.

\section{Stone pine (P. pinea)}

Pure stands of stone pine are estimated to cover a total of 8000 ha, with an additional 731 ha of highly degraded mixed forest of stone pine and oak (Baltaxe, 1965; AbiSaleh et al., 1996). There are 91 pure stands of stone pine, none of which exceed 100 ha, distributed throughout central and southern Lebanon (Fig. 1, Tables 2 and 3) (Baltaxe, 1965). Stone pine grows mainly on sandstone (Abi-Saleh \& Safi, 1998), where it forms dense stands, by contrast to the sparse stands found on calcareous soils (Routier, 1996). We believe that the abundance and dominance of this species is a consequence of its cultivation; the kernels are an important item in Middle Eastern cooking, and the timber is used for furniture and fuel.

\section{Aleppo pine (P. halepensis)}

Aleppo pine is less cold tolerant than other pines in Lebanon (Dereix et al., 1999), and exists in sparse populations covering a total area of 161 ha (Baltaxe, 1965) restricted to the southern part of the country.

\section{Mediterranean cypress (Cupressus sempervirens)}

The Mediterranean cypress is widely distributed along the western flank of the Lebanon range, although it rarely forms dense or pure stands (Mikesell, 1969). In 1965, Baltaxe estimated a total of 82 ha in which Mediterranean cypress dominates, and an additional 728 ha of mixed Mediterranean cypress and Calabrian pine stands, with one-third of these being highly degraded (Baltaxe, 1965). By 1988, the total area covered by cypress had fallen to 500 ha (Abi-Saleh et al., 1996). Mediterranean cypress, along with Calabrian pine and oak ( $Q$. calliprinos), are increasingly colonizing higher altitudes of the western slopes of the Lebanon mountain range in the north, replacing Q. infectoria (Chouchani, 1972).

\section{Cedar of Lebanon (C. libani)}

Pure cedar of Lebanon forests probably once formed a continuous band on the western slopes of the Lebanon chain, but only 15 natural stands remain (Fig. 1), more than half of which are less than 100 ha in area and all in some state of degradation (Chouchani, 1972; Khuri et al., 


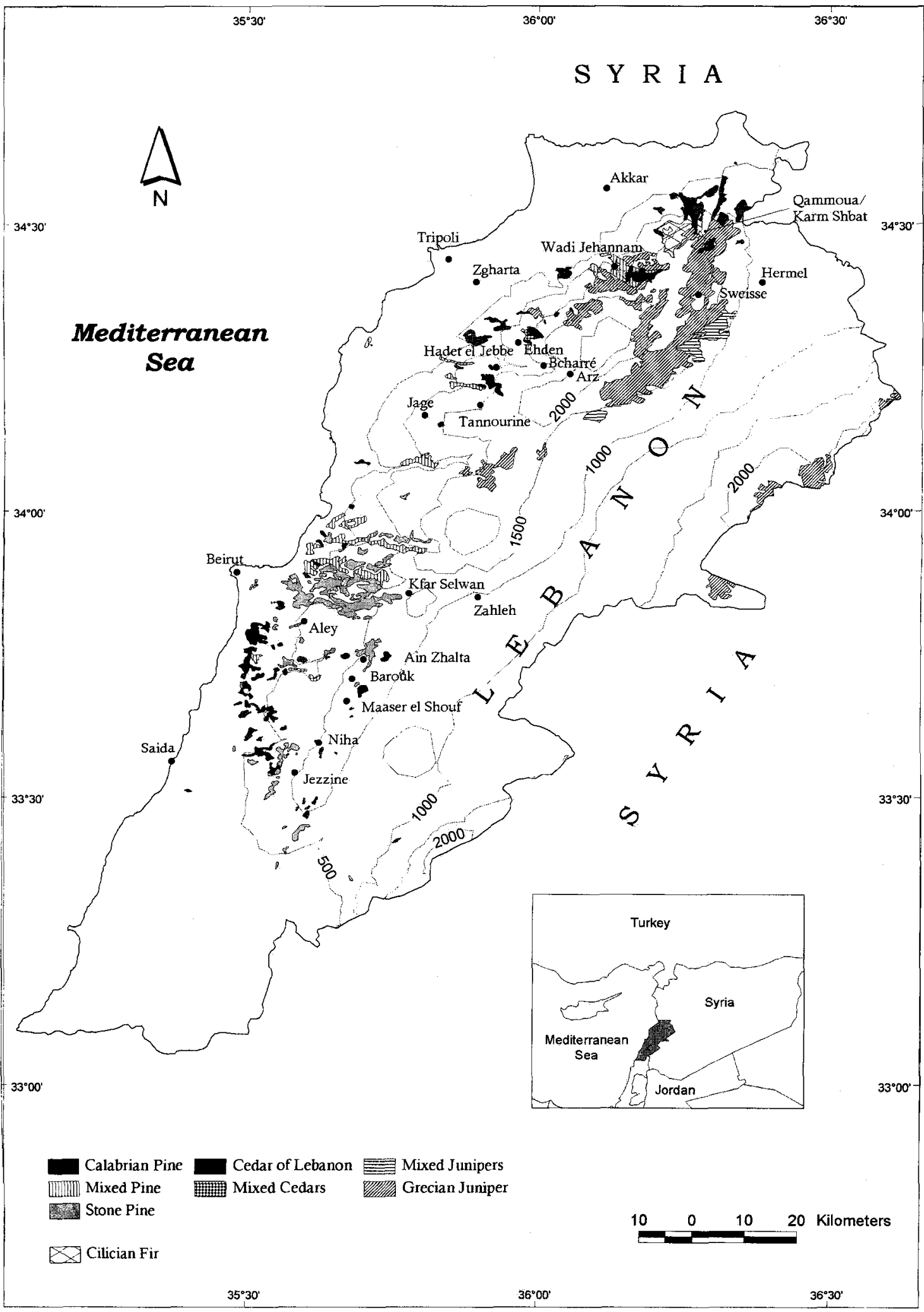

Fig. $\uparrow$ The distribution of conifer species in Lebanon (adapted from Baltaxe, 1965). 
Table 2 Location of conifer populations in Lebanon (after Mouterde, 1966).

\begin{tabular}{|c|c|}
\hline Species & Location \\
\hline Abies cilicica & Ehden forest, Qammoua mountain, Ain Toffaha NE of Seer Eddeniye. \\
\hline Cedrus libani & $\begin{array}{l}\text { Niha mountain, Maaswer el Chouf, Barouk, Ain zehalta, Western slopes of Jaj mountain, } \\
\text { between Tannourine and Hadath, above Bcharre, Ehden forest, Wadi Jehannam north of Seer, } \\
\text { Qammoua, Karm Shbat, Sweise, newly planted sites. }\end{array}$ \\
\hline Cupressus sempervirens & $\begin{array}{l}\text { Maghdouche, Bchetfine, Deir el Kamar, Abey, above Maameltein and Ghazir, above Jbail, } \\
\text { Bcharre, Ehden above the monastery of Mar Sarkis. }\end{array}$ \\
\hline Juniperus drupacea & $\begin{array}{l}\text { Above Mayfouk, Douma, Barouk mountain, Cedar forest of Ain Zhalta, Jabal Moussa above } \\
\text { Mchatta, Denniye, valley of Sirhin north of Seer, between Ehmej and Laqlouq, Cedars, Hermon. }\end{array}$ \\
\hline J. excelsa & $\begin{array}{l}\text { Rarely found south of Beirut - Damascus road. Afqa, Ehden forest, Qammoua forest, slopes } \\
\text { north of Marj Hin and Jabal el Homr, extended woods above Seer, slopes above Cedars, } \\
\text { towards Foum al Mizhab up to } 2800 \mathrm{~m} \text {, upper Akkar, eastern slopes of the Lebanon above the } \\
\text { water sources of Oronte, Yammoune, Ainata and Hermel. On the peaks of the Anti-Lebanon } \\
\text { and in the Hermon. }\end{array}$ \\
\hline 1. foetidissima & Usually associated with Abies. Qammoua between the forest of Qammoua and Hermel. \\
\hline J. oxycedrus & $\begin{array}{l}\text { Rarely below } 500 \mathrm{~m} \text {. El-boum, Yarze one tree was found in } 1932 \text { and has disappeared since, } \\
\text { above Ghazir, more common at higher altitude mainly on gres in Jisr el Qadi, Abey, Bikfaya, } \\
\text { Antouar, Mayrouba, Douma, Qornayel, Seer, Ainzhalta, Jabal Kneisse, Afqa, Jabal Qammoua, } \\
\text { Hermon, above Jdita. }\end{array}$ \\
\hline Pinus brutia & $\begin{array}{l}\text { South towards Bkassine, in Akkar, Saida, Choueifat, Ain Anoub, Souq al Ghareb, Aley, Beit } \\
\text { Mery, Broummana, Baabdate, Bikfaya, Bkerke, Tripoli to Ehden, Ehden forest, forest of } \\
\text { Qammoua. }\end{array}$ \\
\hline P. halepensis & $\begin{array}{l}\text { Below Maghdouche above Saida, between Ain Traz and Rochmaya. Above Choueifat mixed } \\
\text { with } P \text {. brutia. In the woods of Yarze between Baabda and Jamhour. Further north a small } \\
\text { population above Jbail was planted in } 1930 \text {. }\end{array}$ \\
\hline$P$. pinea & $\begin{array}{l}\text { On sandy soils south of Beirut. Maghdouche, above Saida, Abey, Beit meri, Broummana, } \\
\text { Bikfaya, Dhour Choueir, Bois de boulongne, Mrouj. Other cultivated sites. }\end{array}$ \\
\hline
\end{tabular}

\begin{tabular}{lcrrrl}
\hline $\begin{array}{l}\text { Dominant } \\
\text { species }\end{array}$ & $\begin{array}{l}\text { Good } \\
\text { condition }\end{array}$ & Degraded & $\begin{array}{l}\text { Total } \\
\text { cover (ha) }\end{array}$ & $\begin{array}{l}\text { \% of total } \\
\text { forest cover }\end{array}$ & $\begin{array}{l}\% \text { loss between } \\
1968-1989\end{array}$ \\
\hline $\begin{array}{l}\text { Abies cilicica } \\
\text { Cedrus libani }\end{array}$ & - & 1000 & 1000 & 1 & 12 \\
Cupressus sempervirens & 200 & 700 & 2200 & 3 & 10.5 \\
Juniperus excelsa & - & 300 & 500 & 1 & nda \\
Pinus brutia & 5600 & 3400 & 9000 & 13 & nda \\
$\begin{array}{l}\text { P. pinea } \\
\text { Non-conifer oak }\end{array}$ & 5000 & 3000 & 8000 & 13 & nda \\
$\quad$ woodland & 14000 & 26,000 & 40,000 & 57 & nda \\
Total & & & & & \\
\hline
\end{tabular}

Table 3 Area occupied by the major conifer species of Lebanon, indicating the extent of the degraded areas (Abi-Saleh et al., 1996), and the estimated loss between 1968 and 1989 (FAO figures quoted in Darwich et al., 1996).

nda $=$ No data available.

2000); they cover a total area of less than 2300 ha (Khouzami, 1994). A small pure cedar of Lebanon stand in the south in Niha marks the southern limit of the species (Table 2). The cedar of Lebanon forests of the Shouf region comprise dense stands interconnected with sparse populations on the west and north-west slopes. Just north of Beirut are the Tannourine and Hadeth al Jibbeh forests consisting of pure cedar of Lebanon stands located on western and northern slopes. In Hadeth al Jibbeh, the peculiar Himeh cedar of Lebanon stand, occupying $20 \mathrm{ha}$, is unusually located on a sandstone formation, and although healthy, the trees are much smaller in size than counterparts of comparable age on calcareous soils (Beals, 1965). One of the most important relict old-growth cedar of Lebanon stands is in the north, at Bsharre. At $1950 \mathrm{~m}$ this is the upper altitudinal limit of the species. The forested area of the Horsh Ehden reserve extends for 350 ha, over 1200-1950 m, on the north-western slopes of the Mount Lebanon chain. The topography of this site is varied, with a number of steep slopes, and is the richest floristic locality in Lebanon (Beals, 1965; Mouterde, 1966). Parts of this forest are sparsely covered with cedar of Lebanon, Prunus ursina, oak (Q. cerris), Sorbus torminalis 
and junipers ( $J$. excelsa and $J$. oxycedrus). Other areas consist of a dense stand of cedar of Lebanon, Cilician fir, junipers, Berberis libanotica, Acer hyrcanum and S. flabellifolia (Sattout, 1998).

\section{Cilician fir (A. cilicia)}

In Lebanon, Cilician fir is restricted to the northern part of the western mountain range, and reaches its southernmost limit in the forest of Horshe Ehden (Beals, 1965; Zohary, 1973). Further north at Qammoua there is a large and degraded Cilician fir population covering an area of over 1000 ha (Fig. 1). The forest remained intact until World War II, at which time it was exploited by occupying forces (Chouchani, 1972). Currently the landscape shows signs of heavy grazing, with few young fir trees (M. Maunder \& S. Khuri, pers. obs.). Elsewhere, Cilician fir is always found in association with cedar of Lebanon; they both prefer calcareous soil. In these mixed forests, for example at Ehden, Cilician fir tends to prefer more humid locations, whereas the cedar of Lebanon is less restricted by soil moisture (Beals, 1965). At Qammoua there are also highly degraded mixed stands of Cilician fir, cedar of Lebanon and junipers. Their locations in the forest are differentiated at least in part by their moisture requirements, with Cilician fir growing predominantly on the more humid west and north-western slopes, and cedar of Lebanon and Grecian juniper found on the drier north-east and eastern slopes (Beals, 1965; Chouchani, 1972).

\section{Junipers (Juniperus spp.)}

Grecian juniper J. excelsa grows in pure stands or as part of cedar of Lebanon and Cilician fir forests (Fig. 1, Table 2). When found at the same altitudes as the cedar of Lebanon and Cilician fir, it tends to grow in the relatively drier areas (Beals, 1965). Grecian juniper also occurs in xeric areas above $2000 \mathrm{~m}$ and, unlike other Lebanese conifers, extends to the eastern slopes of Mount Lebanon and forms scattered stands on the higher slopes of the Anti-Lebanon (Fig. 1). It is likely that this species once covered the crest of most of the Lebanon and Anti-Lebanon (Mikesell, 1969), where today stands are sparse and often consist of old individuals with little undergrowth or regeneration (S.N. Talhouk \& R. Zurayk, pers. obs.). Little information is available on the distribution of prickly juniper J. oxycedrus, Syrian juniper $J$. drupacea and willdenow I. foetidissima (Post \& Dinsmore, 1933; Mouterde, 1966). Prickly juniper is commonly found associated with oak, pine, and cedar of Lebanon forests, growing mainly in forest clearings. Syrian juniper and willdenow are found at higher altitudes (Chouchani, 1972).

\section{Threats}

\section{Changes in land use}

The montane ecosystems of Lebanon are characterized by steep slopes, intense winter rainfall and long dry summers. Recent uncontrolled expansion of coastal cities and summer mountain resorts, and agricultural expansion in rural areas, have exacerbated land degradation caused by landslides, flash floods and forest fires (Zurayk \& El Moubayid, 1994; METAP, 1995). In addition, there has been a large increase in the number and size of quarries in the hills, and forests in the coastal zones, owned variously by villagers, religious and communal authorities, are becoming fragmented as the real estate value of land at lower elevations increases. Stands of stone pine in these areas used to be managed traditionally by clearing the low vegetation and pruning tree canopies, leaving a 3-5 m crown height. Management has, however, declined in the last 30 years because of the increasing cost of labour and decreasing cost of fuel-wood (Saghie, 2001). More recently roads have been built through the forests to facilitate the transport of harvested cones, and the proliferation of houses has created a glut of solid waste that is dumped and burned near the pine forests.

\section{Burning}

Burning is an integral component of Mediterranean ecology, but the current rate and intensity of fires is causing excessive damage. Forestry service reports indicate that 1200 ha of natural forest are burnt every year (Nasser, 1987). In 1992, 60 fire events were reported, mostly in the pine forest zone (Zurayk, 1994). One of these fires almost completely destroyed 1800 ha of pine, cypress and oak mixed forest in Aley. Another fire in a degraded pine forest in Shouf completely destroyed the forest, causing a loss of more than 50,000 trees (R. Zurayk, pers. obs.). Recently the project 'Defence des Forets du Liban Contre l'Incendie', financed by the French government, has been instrumental in the acquisition of fire-fighting equipment and in training the Lebanese Ministry of Agriculture forest guards in the prevention of forest fires.

\section{Pollution and insect outbreaks}

In the vicinity of Beirut, pine trees are chlorotic, new growth is short, production is low (Routier, 1996), and many trees have malformed crowns and dead branches. At least a proportion of this decline may be attributed to the complex and cumulative effects of air pollution, to 
which Mediterranean conifers are thought to be particularly sensitive (Bussotti \& Ferretti, 1998).

There is an increase in insect attacks on pine stands, and pine-cone collectors have reported a widespread dieback in managed forests. The cause is species of the wood borer Ernobius (Coleoptera), which are known to attack weakened or stressed trees (Kawar et al., 1998). There are records of seasonal outbreaks of the pine processionary moth (Thaumetopeoa wilkinsone Tams., Lepidoptera) on stone pine, a pest that usually attacks Calabrian and Aleppo pine (Kawar et al., 1998).

The decline of the cedar of Lebanon forest in Tannourine is of major concern. Accounts by the local community indicated that during the past 15 years small patches in the cedar of Lebanon forest have turned 'red' and the trees then died. The forest was being attacked by an insect complex consisting of Cephalcia tannourinensis (Hymenoptera) as the primary pest, and the weakened trees then succumbed within 5-6 years to secondary pests of the genera Ernobius (Coleoptera) and Dasineura (Diptera) (N. Nemer, pers. comm.). Efforts are being made to control the primary pest by aerial spraying programmes. Although the outbreak of $C$. tannourinensis is limited to the forest of Tannourine, this pest has also been found in Bsharre. The two other pests are present at low densities in all cedar of Lebanon stands, but do not seem to pose a significant threat (Nemer, 1999).

\section{Cutting and over-grazing}

It is estimated that 800,000 sheep and goats are using woodlands and degraded highlands for at least 2 months per year (FAO, 1989, 1998). Continuous overgrazing has prevented regeneration of forests, especially the slow growing conifers, and compounded the effects of deforestation. The fir forest of Qammoua is one of many examples of ongoing over-exploitation of forests in marginalized rural areas. This area has been supporting wood-cutting activities and a large number of goats for many decades (Beals, 1965; A. Al Khatib pers. comm.). The village communities in the vicinity of the forest typically have low standards of living, and income generation is limited to agropastoral activities and seasonal employment. The exploitation of the neighbouring fir forest is crucial, and villagers cut large quantities of wood for fuel and graze their livestock in the forest for most of the year (Anon., 196-a, verified by $A$. Al Khatib in 1999). We have recently noted similar problems in the cedar of Lebanon stands of Karm Shbat and Sweise. In addition to tree cutting, these areas are being cleared for agricultural activities and quarrying.

\section{Forest conservation efforts}

\section{Past reforestation efforts}

In the 1960s, the Lebanese government put in place a 'Project for the improvement of the Lebanese Mountains', which was the focus for reforestation activities (Anon., 196-b) and constituted the basis of the operation of Green Plan, which is part of the Ministry of Agriculture. With the support of the Food and Agriculture Organization (FAO), land evaluation studies showed that 250,000 ha, or 25 per cent of the land area, could be placed under forest, in addition to the existing c. 70,000 ha, to bring the total forested area to over 30 per cent of Lebanese territory (FAO, 1993). The project prepared 70 reports during 1963-1966, but these were dispersed during the recent war (1974-1990). As a result of this project, reforestation efforts were initiated, with the establishment of mixed stands, including conifers, and the creation of forest nurseries (Anon., 196-b). In the Shouf Mountains, for example, reforestation efforts were undertaken during 1960-1975 to restore cedar of Lebanon forests. A total of 350 ha were planted in Ain Zhalta, Barouk and Maasser Al Shouf. Planned thinning and plot management was interrupted by the recent war, and today the rows of trees are 5-6 $\mathrm{m}$ tall; however, the planting density is very high and many of the trees are stunted (Khuri \& Akeroyd, 1999).

A review of national reforestation activities over the past 10 years, as reported by local newspapers, indicates that several NGOs, working with government agencies and with the support of local and international donors, undertook reforestation campaigns throughout Lebanon. The trees planted were mostly pines, cedar of Lebanon, cypress, junipers, carob and eucalyptus. This effort, although significant socially, cannot meet the projected aim of increasing the forest cover to 30 per cent in the near future. Government nurseries reported the production of 4.2 million seedlings, consisting mostly of native coniferous species, in 1998 (Akl, 1998). This production, however, has not been accompanied by reforestation. In addition, such efforts cannot succeed unless a comprehensive control and follow up operation is implemented and, more importantly, unless the projects enjoy support from the local communities.

\section{Current legislation and establishment of protected areas}

The Forestry Law of 7 January 1949 is the principal legislation for the protection and management of forested areas. However, this law neither puts systems in place for the maintenance and conservation of forests, nor takes into consideration the public use of forests on 
private or public lands. More recently Law 558 (Government of Lebanon, 1996) categorized conifers as protected trees, and decrees have recently been published specifying the location of certain stands, and giving the habitats protected status (Hamze et al., 1996). However, governmental efforts to enforce these decrees are limited by lack of both funds and personnel (Darwich et al., 1996; Akl, 1998). The most recent review of reforestation efforts is a series of reports prepared for the government of Lebanon by the FAO (1993). Only limited implementation of the proposed objectives has occurred so far (F. Asmar, pers. comm.).

In 1992 and 1994, Al Shouf and Ehden forests were designated as Nature Reserves (Hamze et al., 1996), managed by local NGOs subcontracted by the Ministry of Environment within the framework of a GEF/UNDP funded project designed to assess the effectiveness and feasibility of protected areas (Anon., 1997). When the project expires in 2002 the Reserves will remain under the jurisdiction of the Lebanese government, which is currently putting steps in place to ensure that sustainable maintenance endures beyond the life of the project. Al Shouf Reserve is a series of mountains with an area of c. 24,500 ha. Since its protection from grazing, there has been a significant increase in cedar of Lebanon regeneration (pers. obs.). One-third of the 1000 ha of the Ehden Reserve is forested, and this mixed forest consists of diverse habitats that includes seasonal rivers and endemic plant species (Sattout, 1998). These two Nature Reserves are among the last remaining areas in Lebanon where larger mammals such as the jackal and wild boar can still be found.

The protection of other coniferous forests tends to be in areas where cedar of Lebanon dominates, as it is the national tree. The old-growth cedar of Lebanon stand at Bsharre was protected by the local people, for whom it holds religious significance (Khuri et al., 2000), before it became part of a World Heritage Site. The cedar of Lebanon forest of Jage is currently protected by local authorities and, more importantly, by the fact that the local community fully supports this protection. The recent decline in the health of forests in Tannourine has attracted local and governmental attention, and activities such as wood-cutting are no longer permitted.

\section{Integrated conservation systems}

A conservation and reforestation strategy for the coniferous forests of Lebanon will only be sustainable if its objectives have a favourable impact on local communities. The successful protection of the cedar of Lebanon reserves at $\mathrm{Al}$ Shouf and Ehden is a result of their accessibility for eco-tourism and their status as government properties. This is not the case, however, for conifer stands in remote areas of the country or in non-cedar areas where the real estate value of the land is high. In these cases only an integrated approach can be sustainable, and it is imperative that the economic value of forests and forest-related products (Table 4) are taken into account.

An example of such integration is the village of Kfarselwan, where pine/oak stands constitute 30 per cent of village lands (Zurayk, 1994). The forested land is an important economic asset for the village, which relies largely on agriculture for income and for which firewood is the main source of fuel. Ownership of the wooded land is communal, and a set of unwritten local customs and rules prevent degradation and mitigate fire hazards. Management of the land is the responsibility of a council of elders in which all families and clans are represented. The council makes decisions regarding the location of the areas to be logged and the amount that may be removed by each family. Sheep and goats are prevented from entering newly logged areas of forest for a period of 8 years, until the forests have regenerated. Following this, herdsmen are encouraged to graze their flocks in the forest to control the fire-prone undergrowth. Implementation is the responsibility of a forest guard who is hired and paid by the local community. The guard is also responsible for monitoring and giving early warning in case of fires.

\section{Restoration opportunities}

The rural population of Lebanon comprised 59 per cent of the total population in 1961, but this had dropped to 16 per cent by 1990 (Darwich et al., 1996) as a result of movements to the main cities. Furthermore, the agricultural sector is playing a decreasing role in the Lebanese economy; its share of the national GDP has fallen from 12 per cent in 1960 to 8 per cent in 1996 (Darwich et al., 1996). The opportunity now exists therefore to improve mountainous areas by initiating and developing ecological restoration programmes. This unique opportunity may soon be lost, however, as already an increasing proportion

Table 4 Economic value of the Lebanese forests over the years 1993-1994, derived in part from Darwich et al. (1996).

\begin{tabular}{lcl}
\hline Product or service & Value (US \$/annum) & Current trends \\
\hline Sport/hunting & $531,250,000$ & Increasing \\
$\begin{array}{l}\text { Timber - industrial and } \\
\quad \text { worked wood }\end{array}$ & $108,000,000$ & Constant \\
Pine kernels & $58,320,000$ & Decreasing \\
Honey & $14,250,000$ & Constant \\
Medicinal plants & $6,112,500$ & Increasing \\
Charcoal & 455,000 & Constant \\
Livestock & 52,500 & Constant \\
Tourism & 29,000 & Increasing \\
Watershed services & No data available & Increasing \\
\hline
\end{tabular}


of land is being taken over for the construction of hotels or weekend villas for affluent city-dwellers, an exercise that continues largely uncontrolled.

\section{Conclusions}

Lebanon is home to 10 conifer species, most of which have been exploited throughout history for timber and fuel. Although none of these species are considered highly threatened in a global context (Table 1), their conservation must be an essential component of any national response to maintain biodiversity over the extensive semi-natural and anthropogenic landscapes of Lebanon. Both the increased demand for real estate and the degradation and fragmentation of conifer woodlands seem set to continue. Unless a long-term conservation strategy is adopted, it is likely that low-mid altitude forests will disappear in the near future and that there will be irreversible degradation of upland forest habitats.

A starting point for a conservation strategy for the conifers of Lebanon would be to apply that proposed by Yanchuk \& Lester (1996) for British Columbia; namely, to maintain existing protected areas, to create new protected areas for in situ management, and to employ ex situ conservation for the species in question. At the moment, however, Lebanon has only two forested areas under managed protection, the Nature Reserves of Ehden and Al Shouf, and although there are other areas protected by ministerial decrees, few are managed as nature reserves.

There is clearly a need to invest in the long-term management of the few existing protected areas. We propose that a suitable conservation strategy for Lebanese conifers would be to apply biosphere management procedures to a linked series of ecosystem reserves (Khuri \& Talhouk, 1999). This would not only serve to protect conifer species and their habitats, but would also allow for small-scale commercial exploitation for the benefit of local communities. Although further research may still be required to define specific measures, we recommend that a multidisciplinary, fully integrated ecosystem approach is employed in Lebanon. This is the only manner in which the Lebanese conifers and their habitats can be sustainably maintained.

\section{Acknowledgements}

The authors thank the anonymous referees for their constructive comments, Dr Mike Maunder (National Tropical Botanic Garden, Hawaii) for valuable discussions on the manuscript, and Ms. Elsa Sattout (University of Reading, UK) for her useful comments. The authors are also grateful to Ms. Nahed Debian and Mr Dany Lichaa for digitizing and preparing the conifer distribution map.

\section{References}

Abi-Saleh, B. \& Safi, S. (1998) Carte de la vegetation du Liban. Ecologia Mediterranea XIV (1/2).

Abi-Saleh, B., Nasser, N., Rami, H., Safi, N., Safi, S. \& Tohme, H. (1996) Terrestrial flora. In Biological Diversity of Lebanon Comprehensive Report (eds S. Hamadeh, M. Khouzami and G. Tohme), pp. 65-94. Publication no. 9, report to the Lebanese Government Sponsored by UNEP Project GF/ 6105-92-72, Beirut, Lebanon.

Akl, G. (1998) Integrating Criteria and Indicators of Sustainable Forest Management in the National Forest Programs. Report for the Ministry of Agriculture, The Government of Lebanon.

Anon. (196-a) Some Proposals for Action in Fneideq to save Qammoua Forest. Project for the integrated improvement of the Lebanese Mountain, Food and Agricultural Organization, Green Plan, The Republic of Lebanon.

Anon. (196-b) Projet de bonification integrale de la montagne Libanaise: Formation et Recherches Forestieres. Rapport final \& PlanVert, Republic Libanaise.

Anon. (1997) Lebanon: Strengthening of National Capacity and Grassroots in-situ Conservation for Sustainable Biodiversity Protection. Project Document, Global Environmental Facility, Beirut, The Republic of Lebanon.

Baltaxe, R. (1965) Report on Mapping the Forests of Lebanon. Green Plan, the Government of Lebanon, Prepared by Food and Agricultural Organization for the Republic of Lebanon, Beirut, Lebanon.

Beals, E.W. (1965) The remnant cedar forests of Lebanon. Journal of Ecology, 53, 679-694.

Bowton, M.B. (1965) The topological factor in the Hapiru problem. In Studies in Honor of Benno Landsberger (eds H. G. Guterbock and T. Jacobsen), pp. 375-387. Chicago.

Bussotti, F. \& Ferretti, M. (1998) Air pollution, forest condition and forest decline in Southern Europe: an overview. Environmental Pollution, 101, 49-65.

Chouchani, B. (1972) Le Liban: Contribution à son étude climatique et phytogeographique. Mémoire du doctorat de 3ème cycle, Universite de Toulouse, Toulouse.

Darwich, R., Hamadeh, S., Hayek, A. \& Serhal, J. (1996) Economic assessment of the biodiversity. In Biological Diversity of Lebanon - Comprehensive Report (eds S. Hamadeh, M. Khouzami and G. Tohme), pp. 185-203. Publication no. 9, report to the Lebanese Government sponsored by UNEP project GF/6105-92-72, Beirut, Lebanon.

Davis, S.D., Heywood, V.H. \& Hamilton, A.C. (eds) (1994) Centres of Plant Diversity: a Strategy for their Conservation, Vol. 1. Europe, Africa, South West Asia and the Middle East, pp. 324-342. IUCN/WWF. IUCN Publications Unit, Cambridge.

Dereix, C., Ohannessian-Charpin, A., Khouzami, M. et al. (1999) Les principaux arbres du Liban: Le fascicule des essences forêstières du Liban. Projet d'Assistance à la Protection de la Couverture Végétale au Liban, European Union and the Lebanese Ministry of Agriculture.

FAO (1989) Production Yearbook, Vol. 43. Food and Agriculture Organization, Rome, Italy.

FAO (1993) Assistance au reboisement. Programme de Cooperation FAO/Liban. Food and Agriculture Organization, Beirut, Lebanon. 
FAO (1998) Production Yearbook, Vol. 52. Food and Agriculture Organization, Rome, Italy.

FAO (2000) Page for Lebanon at http:/ /www.fao.org/forestry/

Farjon, A. (1998) World Checklist and Bibliography of Conifers. Royal Botanic Gardens, Kew.

Farjon, A. \& Page, C.N. (compilers) (1999) Conifers. Status Survey and Conservation Action Plan. IUCN/SSC Conifer Specialist Group. IUCN, Gland Switzerland and Cambridge, UK.

Farjon, A., Page, C.N. \& Schellevis, N. (1993) A preliminary world list of threatened conifer taxa. Biodiversity and Conservation, 2, 304-326.

Glowka, L., Burhenne-Guilmann, F., Synge, H., McNeely, J.A. \& Gündling, L. (1994) A Guide to the Convention on Biological Diversity. Environmental Policy and Law Paper no. 30, IUCN, Switzerland.

Government of Lebanon (1996) Law number 558. Protection of Forests. Aljarida Alrasmiya, 34, 1 August 1996.

Hamze, M., Abi Antoun, M., El-Hajj, S., Hamadeh, S. \& Tohme, H. (1996) Lebanon Country Study on Biological Diversity. Project GF/6105-92-72, Publication no. 7, Beirut, Lebanon.

Hilton-Taylor, C. (compiler) (2000) IUCN Red List of Threatened Species. IUCN, Gland, Switzerland and Cambridge, UK.

Kawar, N.S., El-Masri, T., Abou Fakhr, E. \& Tohme, H. (1998) Identification and study of insects and pests in the Pinus pinea forests in Lebanon. Lebanese Abstracts, II.c, 235.

Khouzami, M. (1994) The Lebanese cedar forests. In Proceedings of the First National Conference on the Cedar of Lebanon, Present and Future. American University of Beirut, Lebanon.

Khuri, S. \& Akeroyd, J. (1999) Cherishing Lebanon's famous cedars. Plant Talk, 17, 19-21.

Khuri, S., Shmoury, M.R., Baalbaki, R., Maunder, M. \& Talhouk, S.N. (2000) Conservation of the Cedrus libani populations in Lebanon: History, current status and experimental application of somatic embryogenesis. Biodiversity and Conservation, 9, 1261-1273.

Khuri, S. \& Talhouk, S.N. (1999) Cedar of Lebanon (Cedrus Libani A. Rich.) In Conifers. Status Survey and Conservation Action Plan (compilers A. Farjon and C.N. Page), 108-111. IUCN/SSC Conifer Specialist Group. IUCN, Gland Switzerland and Cambridge, UK.

Medail, F. \& Quézel, P. (1997) Hot-spots analysis for conservation of plant diversity in the Mediterranean basin. Annals of the Missouri Botanic Garden, 84, 112-127.

Meiggs, R. (1982) Trees and Timber in the Ancient Mediterranean World. Clarendon Press, Oxford.

METAP (Mediterranean Environmental Technical Assistance Program) (1995) Lebanon: Assessment of the State of the Environment, for the Ministry of Environment. Final Report,
EU/EIB/WB/UNDP, Prepared by Environmental Resources Management Resources.

Mikesell, M.W. (1969) The deforestation of Mount Lebanon. Geographical Review, 19, 1-28.

Mouterde, P. (1966) Nouvelle Flore du Liban et de la Syrie, Vol. 1, editions de l'imprimerie catholique, Beyrouth.

Myers, N., Mittermeier, R.A., Mittermeier, C.G., da Fonseca, G.A.B. \& Kent, J. (2000) Biodiversity hotspots for conservation priorities. Nature, 403, 853-858.

Nasser, M. (1987) Report of the Lebanese Forest Service. Ministry of Agriculture, Beirut, Lebanon.

Nemer, N. (1999) Report on the Increased Decline of Tannourinehadet El Jibbe Cedars Forest. Ministry of Agriculture, Republic of Lebanon.

Post, G.E. \& Dinsmore, J.E. (1933) Flora of Syria, Palestine, and Sinai, Vol. I-II, 2nd edn. American University of Beirut Press, Beirut.

Routier, J. (1996) Analyse des forêts de pin parasols (Pinus pinea L.) au Liban. Project en aménagement forestier, Faculté de forestière, Université Laval.

Saghie, M. (2001) Characterization and evaluation of the biological diversity of Pinus pinea in Lebanon. MSc thesis, American University of Beirut, Beirut.

Sanlaville, P. (1977) Etude Géomorphologique de la Région Littorale Du Liban, Vol. 1. Université Libanaise, Beyrouth.

Sattout, E. (1998) Ecogeographical Study of Calamintha vulgaris $L$., Micromeria graeca, Micromeria serpyllifolia var. barbata and Origanum libanoticum in the Ehden Forest Reserve, Horsh Ehden, Lebanon. MSc thesis, Mediterranean Agronomic Institute of Chania, Greece.

Speiser, E.A. (1955) Akkadian myths and epics. In Ancient Near Eastern Texts Relating to the Old Testament (ed. J. B. Pritchard), 2nd edn, pp. 72-99. Princeton Press, Princeton.

Wilson, J.A. (1955) Egyptian historical texts. In Ancient Near Eastern Texts Relating to the Old Testament (ed. J. B. Pritchard), 2nd edn, pp. 227-264. Princeton Press, Princeton.

Yanchuk, A.D. \& Lester, D.C. (1996) Setting priorities for conservation of the conifer genetic resources of British Colombia. Forestry Chronicle, 72, 406-415.

Zohary, M. (1973) Geobotanical foundations of the Middle East. Verlag-Swets-Zeitlinger, Amsterdam.

Zurayk, R.A. (1994) The role of the local community in the prevention and mitigation of forest fires: Case studies from Lebanon. ICDO Journal, 7, 31-34.

Zurayk, R. \& El Moubayid, L. (1994) Land Degradation and Mitigation in the Lebanese Mountains: The Breakdown of Traditional Systems. Research Paper no. 9, Disaster Management Training Program, UNDP/DHA, New York.

\section{Biographical sketches}

Salma N. Talhouk is Associate Professor of Horticulture at the American University of Beirut (AUB). She gained her PhD from Ohio State University, USA. Her research interests are in morphological and molecular characterization of the diversity of native Lebanese plants, and the use of horticultural techniques for their reintroduction and domestication. Salma Talhouk is currently Coordinator of the Undergraduate Program in Landscape Design and Eco-Management at AUB.

Rami Zurayk is Associate Professor of soil science and ecosystem management at the American University of Beirut. He was awarded his D.Phil from Oxford University, UK. Rami Zurayk has worked in community development in Yemen, and joined AUB in 1991. He is currently Director of the Inter-faculty Environmental Sciences Program at AUB.

Sawsan Khuri is both an Honorary Research Fellow at The University of Reading, UK, and a Research Associate at the National Tropical Botanical Garden, Hawaii, USA. She gained her PhD from the University of London. She combines research interests in plant physiology and bioinformatics alongside her activities in the conservation of Mediterranean habitats. 